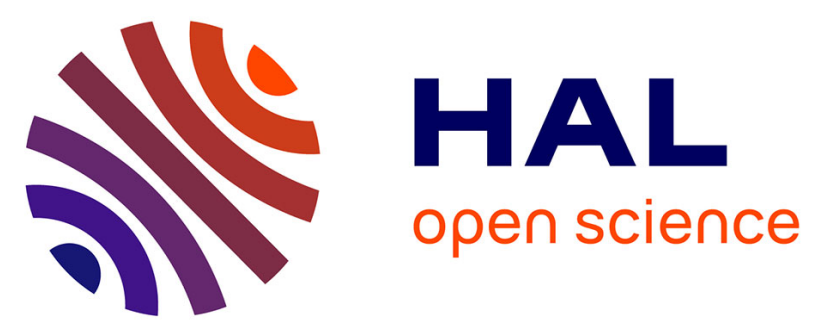

\title{
Optimization of Free Phytoprostane and Phytofuran Production by Enzymatic Hydrolysis of Pea Extracts Using Esterases
}

\author{
R. Domínguez-Perles, I. Sánchez-Martínez, M. D Rodríguez-Hernández, I. \\ López-González, Camille Oger, A. Guy, Thierry Durand, J. M Galano, F. \\ Ferreres, A. Gil-Izquierdo
}

\section{To cite this version:}

R. Domínguez-Perles, I. Sánchez-Martínez, M. D Rodríguez-Hernández, I. López-González, Camille Oger, et al.. Optimization of Free Phytoprostane and Phytofuran Production by Enzymatic Hydrolysis of Pea Extracts Using Esterases. Journal of Agricultural and Food Chemistry, 2020, 68 (11), pp.34453455. 10.1021/acs.jafc.9b06624 . hal-03248118

\section{HAL Id: hal-03248118 \\ https://hal.umontpellier.fr/hal-03248118}

Submitted on 3 Jun 2021

HAL is a multi-disciplinary open access archive for the deposit and dissemination of scientific research documents, whether they are published or not. The documents may come from teaching and research institutions in France or abroad, or from public or private research centers.
L'archive ouverte pluridisciplinaire HAL, est destinée au dépôt et à la diffusion de documents scientifiques de niveau recherche, publiés ou non, émanant des établissements d'enseignement et de recherche français ou étrangers, des laboratoires publics ou privés. 


\title{
Optimization of Free Phytoprostane and Phytofuran Production by Enzymatic Hydrolysis of Pea Extracts Using Esterases
}

\author{
R. Domínguez-Perles, ${ }^{\S}$ I. Sánchez-Martínez, ${ }^{\S}$ M. D. Rodríguez-Hernández, I. López-González, C. Oger, \\ A. Guy, T. Durand, J. M. Galano, F. Ferreres, and A. Gil-Izquierdo*
}

\begin{abstract}
Given the growing interest in phytoprostanes (PhytoPs) and phytofurans (PhytoFs) in the fields of plant physiology, biotechnology, and biological function, the present study aims to optimize a method of enzymatic hydrolysis that utilizes bacterial and yeast esterases that allow the appropriate quantification of PhytoPs and PhytoFs. To obtain the highest concentration of PhytoPs and PhytoFs, a response surface methodology/Box-Behnken design was used to optimize the hydrolysis conditions. Based on the information available in the literature on the most critical parameters that influence the activity of esterases, the three variables selected for the study were temperature $\left({ }^{\circ} \mathrm{C}\right)$, time $(\mathrm{min})$, and enzyme concentration (\%). The optimal hydrolysis conditions retrieved differed between PhytoPs $\left(21.5{ }^{\circ} \mathrm{C}, 5.7 \mathrm{~min}\right.$, and $0.61 \mu \mathrm{g}$ of enzyme per reaction) and PhytoFs $\left(20.0{ }^{\circ} \mathrm{C}\right.$, 5.0 $\mathrm{min}$, and $2.17 \mu \mathrm{g}$ of enzyme per reaction) and provided up to 25.1- and 1.7-fold higher contents relative to nonhydrolyzed extracts. The models were validated by comparing theoretical and experimental values for PhytoP and PhytoF yields (1.01 and 1.06 theoretical/experimental rates, respectively). The optimal conditions were evaluated for their relative influence on the yield of individual nonesterified PhytoPs and PhytoFs to define the limitations of the models for obtaining the highest concentration of most considered compounds. In conclusion, the models developed provided valuable alternatives to the currently applied methods using unspecific alkaline hydrolysis to obtain free nonesterified PhytoPs and PhytoFs, which give rise to more specific hydrolysis of PhytoP and PhytoF esters, reducing the degradation of free compounds by classical chemical procedures.
\end{abstract}

KEYWORDS: plant oxylipins, response surface methodology, Box-Behnken, esterase, enzymatic hydrolysis, free plant oxylipins

\section{INTRODUCTION}

In recent decades, national and international organizations that are focused on the promotion of human health have extensively discussed the benefits associated with the consumption of plant-based foods, concluding that diverse bioactive nutrients and non-nutrients endow them with powerful biological capacities. ${ }^{1-3}$ In this respect, to date, a number of scientific publications have characterized the phytochemical profile of plant-based foods in regard to diverse molecular families. However, when a new family of compounds emerges, the limited availability of standard compounds constitutes a serious drawback for the correct and accurate development of targeted metabolomic studies. ${ }^{4}$ Thus, through the initial stages of characterizing newly identified molecules, the focus of the research efforts should be on the development of appropriate and specific methods, including hydrolysis procedures for obtaining free compounds and the identification of derivatives in plant foods and biological samples. ${ }^{5-8}$

In reference to the challenge of identifying new bioactive compounds, recently, the presence of oxygenated metabolites of $\alpha$-linolenic acid (ALA, 18:3, $\omega 3$ ) has been described in plant-based foods, formed by nonenzymatic oxidative reactions that under diverse oxygen pressures give rise to dinor isoprostanes or phytoprostanes (PhytoPs) and phytofurans (PhytoFs). ${ }^{8}$ These compounds have been characterized on their role in plant nutrition and physiology, while their structural similarity to human oxylipins (prostanoids and isoprostanoids), synthesized in humans from arachidonic acid (AA), has suggested a biological activity in humans, as reviewed by Medina et al. ${ }^{7}$ In this regard, the functional properties of these compounds could be a consequence of the interactions of the reactive units in the structure of PhytoPs and PhytoFs (cyclopentenone ring and/or carboxyl groups, among others) with cysteine residues of proteins that are essential for the normal development of cell metabolism. ${ }^{9-12}$ In regard to the current knowledge on the biological relevance of PhytoPs and PhytoFs, an array of studies have characterized their immunomodulatory potential. ${ }^{7,13}$ In agreement with the recent review by Medina et al., plant oxylipins have been demonstrated to be competent in modulating cellular mechanisms involved in adaptive immunological responses. In this aspect, these PhytoPs and PhytoFs polarize T-cells toward a type 2 helper ( $\mathrm{TH} 2$, proallergenic) response by inhibiting the production of IL-12 by dendritic cells and thus activating mechanisms dependent on the peroxisome pro- 
liferator-activated receptor $\gamma$ (PPAR- $\gamma)$ and the inhibition of NF-kB. Thus, the recent description of these compounds in plant foods has aroused great interest based on the body of evidence on their biological interest already gathered and their structural similarity to bioactive oxylipins in mammals, although these aspects should be characterized in detail in future. $^{7,13}$

However, a constraint to the current interest in the biological functions of these compounds is found in the information gap on the chemical species of PhytoPs and PhytoFs present in plant-based foods and consequently on the availability of true standards for such compounds, which does not allow establishing their absolute concentration in plant tissues. In this respect, the availability of nonesterified standard compounds relies only on the hydrolyzation of PhytoP and PhytoF extracts to avoid underestimations of their concentrations. At present, the hydrolysis of PhytoPs and PhytoFs for free compounds is performed by alkaline hydrolysis using a saturated solution of $\mathrm{KOH} .^{14,15}$ Nonetheless, the harsh reaction conditions associated to this technique could compromise the stability of PhytoPs and PhytoFs through the modification of the functional groups in the target molecules, which constitutes a constraint for the functional characterization of such extracts/compounds. ${ }^{16}$ This limitation could be partially overcome by developing an enzymatic hydrolysis method, although this approach still needs further optimization, which is in line with the current demand for the improvement of methods for the extraction of oxylipins, especially given their low concentrations in samples. ${ }^{17}$

Due to these reasons, the aim of the present research is to establish reliable conditions for the efficient enzymatic hydrolysis of PhytoP and PhytoF esters, enhancing the efficiency for obtaining free acids. Hence, the capacity of diverse esterases (from Bacillus stearothermophilus, Saccharomyces cerevisiae, Bacillus subtilis, and Pseudomonas fluorescens) was tested for their ability to hydrolyze PhytoP and PhytoF esters. Once the most efficient enzyme was identified, a pilotscale response surface methodology (RSM) model was applied to optimize variables influencing the enzymatic reaction (concentration, temperature, and reaction time). This model had been previously successfully applied for the optimization of the extraction conditions for obtaining bioactive phytochemicals from diverse foods and foodstuffs. ${ }^{18-20}$ This method integrates a collection of mathematical and statistical algorithms, reducing the time and resources required for the optimization of processes, where the variables of interest are influenced by independent factors, ${ }^{18}$ thereby also providing valuable information on the interactions between them.

\section{MATERIALS AND METHODS}

Chemicals and Reagents. The reagents hexane, hydrochloric acid, and ethanol were acquired from Panreac (Castellar del Valles, Barcelona, Spain). 2-[Bis(2-hydroxyethyl)amino]-2-(hydroxymethyl)propane-1,3-diol (Bis-Tris), butylhydroxyanisole (BHA), and the bacterial (B. stearothermophilus, B. subtilis, and P. fluorescens) and yeast (S. cerevisiae) esterases were purchased from Sigma-Aldrich (St. Louis, MO). Methanol and acetonitrile were from J.T. Baker (Phillipsburg, NJ). The solid-phase extraction (SPE) cartridges Strata X-AW (100 $\mathrm{mg} / \mathrm{mL})$ and Sep-Pack $\mathrm{C}_{18}(360 \mathrm{mg})$ were acquired from Phenomenex (Torrance, CA) and Waters (MA), respectively. All solvents were of analytical grade. Ultrapure water was from a Milli-QA10 water purification system (Millipore, Bedford, MA).

The standards of PhytoPs and PhytoFs (9- $\mathrm{F}_{1 \mathrm{t}}-\mathrm{PhytoP}$, 9-epi-9- $\mathrm{F}_{1 \mathrm{t}^{-}}$

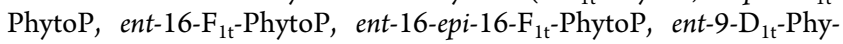

toP, ent-9-epi-9- $\mathrm{D}_{1 \mathrm{t}}$-PhytoP, 16- $\mathrm{B}_{1}$-PhytoP, 9- $\mathrm{L}_{1}$-PhytoP, ent-16-(RS)9-epi-ST- $\Delta^{14}-10$-PhytoF, ent-9-(RS)-12-epi-ST- $\Delta^{10}-13-$ PhytoF, and ent-16-(RS)-13-epi-ST- $\Delta^{14}$-9-PhytoF) were synthesized by the Institut des Biomolécules Max Mousseron (IBMM) (Montpellier, France) according to previous reports. ${ }^{21-24}$

Plant Material and Sample Preparation. Fresh pea (Pisum sativum L.) seeds used as a source of PhytoPs and PhytoFs were acquired from local markets (Murcia, Spain), thus providing homogeneous samples according to commercial standards in terms of maturity. In addition, to avoid deviations due to a lack of uniformity of the plant material, for analytical purposes, peas were mixed thoroughly, to be pooled again into three well-mixed replicates $(n=3)$ per extraction condition. The samples were then flash-frozen using liquid nitrogen and kept at $-80{ }^{\circ} \mathrm{C}$ until freeze-dried (Christ $\alpha$ 1-4D, Christ, Osterode am Harz, Germany). The lyophilized material was crushed in a mill (Janke \& Kunkel, mod. A10, IKA-191 Labortechnik) for approximately $20 \mathrm{~s}$, passed through a $0.5 \mathrm{~mm}$ sieve, packed in polypropylene containers, and stored at $-80{ }^{\circ} \mathrm{C}$ until the extraction of PhytoPs and PhytoFs.

Extraction of Phytoprostanes and Phytofurans. The PhytoPs and PhytoFs from peas were extracted following the methodology described previously by Collado-González et al. ${ }^{25}$ and Pinciroli et al., ${ }^{26}$ with minor modifications. Briefly, samples $(400 \mathrm{mg})$ were dissolved in $1 \mathrm{~mL}$ of methanol/BHA (99.9:0.1, v/w), sonicated for 10 min at room temperature (Branson 3510MT sonicator, ultrasonic frequency $40 \mathrm{kHz}$, Sigma-Aldrich, St. Louis, MO), stirred in a vortex, and centrifuged at $2000 \mathrm{~g}$ for $10 \mathrm{~min}$ at room temperature. After centrifugation, supernatants were filtered through a Sep-Pack $\mathrm{C}_{18}$ classic cartridge $(360 \mathrm{mg}$ ) (Waters, Milford, MA), preconditioned with $10 \mathrm{~mL}$ of methanol and $10 \mathrm{~mL}$ of Milli-Q water, and dried with $10 \mathrm{~mL}$ of air using a $10 \mathrm{~mL}$ syringe for each fluid. One milliliter of the filtered extracts was removed from each sample and hydrolyzed through the application of a range of hydrolysis conditions in regard to temperature, extraction time, and enzyme concentration described in the next section.

Hydrolysis. The starting conditions for the design of the RSM model addressed to optimize the hydrolysis of PhytoPs and PhytoFs esters by esterases from B. stearotermophilus, S. cerevisiae, B. subtilis, and $P$. fluorescens were chosen upon a preliminary characterization of the hydrolysis capacity of the enzymes selected. This was done according to the information available in the literature regarding the most relevant factors (enzyme concentration, duration of the reaction, and reaction temperature). ${ }^{27,28}$ Thus, these preliminary analyses were conducted by adding $50 \mu \mathrm{L}$ of enzyme $(20 \mu \mathrm{g} / \mathrm{mL})$ and $200 \mu \mathrm{L}$ of $0.02 \mathrm{M}$ Bis-Tris ( $\mathrm{pH} 7.0$ ) to $200 \mu \mathrm{L}$ of PhytoP/PhytoF pea extracts. The hydrolysis reactions were carried out at $25^{\circ} \mathrm{C}$ for 10 and $20 \mathrm{~min}$, in agreement with the previous descriptions available on the enzyme requirements. $^{27,28}$ Afterward, the esterase activity was stopped by adding $200 \mu \mathrm{L}$ of methanolic $\mathrm{HCl}(200 \mathrm{mM})$. The hydrolyzed samples were centrifuged at $15000 \mathrm{rpm}$ for $5 \mathrm{~min}$ at $4{ }^{\circ} \mathrm{C}$, and the supernatants were collected. The results shown are representative of three independent experiments.

Alkaline hydrolysis developed in reference to the results obtained on enzymatic hydrolysis was performed according to the methodology described by Leung et al. ${ }^{14}$

To remove molecules that could potentially interfere with the ionization of PhytoPs and PhytoFs during the ultrahigh-performance liquid chromatography coupled to electrospray ionization and triple quadrupole mass spectrometry (UHPLC-ESI-QqQ-MS)/MS analysis, the hydrolyzed extracts were cleaned up with SPE, using strata X-AW cartridges (Phenomenex, Torrance, CA), according to the previously described methodology. ${ }^{25}$ The PhytoPs and PhytoFs eluted were dried using a speed vacuum concentrator (Savant SPD121P, Thermo Scientific, MA), and the dried extracts were reconstituted with $200 \mu \mathrm{L}$ of Milli-Q water/methanol (50:50, v/v), sonicated for $10 \mathrm{~min}$, and filtered through a $0.45 \mu \mathrm{m}$ pore size filter (Millipore, MA).

UHPLC-ESI-QqQ-MS/MS Analysis of Phytoprostanes and Phytofurans. The hydrolyzed PhytoPs and PhytoFs were analyzed by ultrahigh-performance liquid chromatography (UHPLC), coupled to an electrospray ionization triple quadrupole mass spectrometer 
(ESI-QqQ-MS/MS, Agilent Technologies, Waldbronn, Germany), using the method developed and validated by Collado-González et al. for PhytoPs and complemented by Dominguez-Perles et al. ${ }^{25,29}$ relatively to PhytoFs. The quantification of free PhytoPs and PhytoFs was performed with previously reported molecular transitions ${ }^{29}$ by utilizing authentic standard curves, which were freshly prepared each day of analysis.

Experimental Design and Statistical Analysis. For the optimization of the enzymatic hydrolysis of PhytoP and PhytoF esters relative to the variables temperature $\left({ }^{\circ} \mathrm{C}, X_{1}\right)$, extraction time ( $\min , X_{2}$ ), and the enzyme concentration ( $\mu \mathrm{g}$ of enzyme, $X_{3}$ ), a BoxBehnken design (Table 1) was developed, which included 15

Table 1. Symbols and Coded Factor Levels for the Considered Independent Variables

\begin{tabular}{lcccc} 
& & \multicolumn{3}{c}{ levels } \\
\cline { 3 - 5 } independent variables & code & -1 & 0 & 1 \\
temperature $\left({ }^{\circ} \mathrm{C}\right)$ & $X_{1}$ & 20 & 35 & 50 \\
time $(\min )$ & $X_{2}$ & 5 & 20 & 35 \\
enzyme per reaction $(\mu \mathrm{g})$ & $X_{3}$ & 0.5 & 2.0 & 3.5 \\
\hline
\end{tabular}

independent experiments. The model was developed by applying random combinations of the variables. The hydrolyzed extracts were assessed for the concentration of total free PhytoPs and PhytoFs (Table 2). All of the experiments were carried out in triplicate $(n=3)$. Three conditions of the Box-Behnken design, randomly distributed in the design, corresponded to the center of the own design $\left(X_{1}(0) 35\right.$ ${ }^{\circ} \mathrm{C}, X_{2}(0) 20 \mathrm{~min}$, and $X_{3}(0) 2 \mu \mathrm{g}$ of enzyme). This, together with the randomized design of the model, minimized the unexplained variability in the observed response due to extraneous factors (Table 2).

The development of the RSM/Box-Behnken model proposed provided two second-order polynomial models that constitute independent variable functions to predict the theoretical contents of total free PhytoPs and PhytoFs. The coefficients corresponding to the model equation were obtained using Statgraphics Centurion XV.I software (StatPoint Technologies, Inc., Warrenton, VA).

When a comparison between more than two groups of variables was required, analysis of variance (ANOVA) and Tukey's multiple range test were employed, using the concentration of total PhytoPs and PhytoFs as sources of variation. The analyses were carried out using IBM SPSS statistics 24.0 software (SPSS Inc., Chicago, IL). The level of significance was set at $p<0.05$.

\section{RESULTS AND DISCUSSION}

At present, and in regard to PhytoPs and PhytoFs, diverse scientific publications have characterized procedures of organic synthesis to obtain nonesterified PhytoPs ${ }^{4,30}$ and PhytoFs, ${ }^{21,22,31}$ while the synthesis of esterified forms has not been reported thus far. In connection with the limited range of PhytoP and PhytoF standards available, the concentration of these compounds in plant foods and biological samples may be underestimated due to the occurrence of esterified derivatives (mainly with phospholipids and triglycerides ${ }^{32}$ ), which are not properly detected and quantified. This problem has been initially addressed by the development of unspecific alkaline hydrolysis. ${ }^{14,15}$ Nonetheless, the detrimental effects on the stability of PhytoPs and PhytoFs treated with this type of hydrolysis could result in serious constraints when processing samples to obtain free (nonesterified) PhytoPs and PhytoFs. ${ }^{16}$ This situation has forced the search for alternative solutions.

With the objective of achieving more efficient and specific hydrolysis of esterified PhytoPs and PhytoFs, the use of bacterial and yeast esterases with the capacity to hydrolyze the esters bonds on the PhytoPs and PhytoFs was hypothesized to be a viable solution. Hence, in the present work, the candidate esterases were selected according to the information available in the existing literature, the commercial availability, and the working conditions in terms of temperature, reaction time, and enzyme concentration. In this respect, although $\mathrm{pH}$ is an important factor that influences the efficiency of the enzymatic reaction, the optimal activity of the enzymes used in this work is at $\mathrm{pH} 7.0 .^{27,28}$ Thus, to simplify the experimental design, the $\mathrm{pH}$ value for all reactions was fixed to $\mathrm{pH}$ 7.0. To complete the optimization of the enzymatic hydrolysis conditions, this was conducted on PhtyoP and PhytoF extracts from peas. This food matrix was selected based on previous works, which characterized the presence of PhytoPs and PhytoFs in plant foods, stressing the value of legumes as a dietary source of these compounds. ${ }^{33}$ However, given that the enzymatic hydrolysis is done on PhytoP and PhytoF extracts and not

Table 2. Effect of Processing Variables on the Concentration $(\mu \mathrm{g} / \mathrm{kg} \mathrm{dw})$ of Total Phytoprostanes and Phytofurans in Commercial Pisum sativum L. ${ }^{b}$

\begin{tabular}{|c|c|c|c|c|c|c|c|}
\hline \multirow[b]{2}{*}{ assay } & \multicolumn{3}{|c|}{ coded level } & \multicolumn{2}{|c|}{ total phytoprostanes } & \multicolumn{2}{|c|}{ total phytofurans } \\
\hline & temperature $\left({ }^{\circ} \mathrm{C}\right)$ & time $(\min )$ & enzyme $(\mu \mathrm{g})$ & observed & theoretic & observed & theoretic \\
\hline 1 & $0(35)$ & $-1(5)$ & $1(3.5)$ & $7874.63 \pm 847.31$ & 8547.33 & $1450.70 \pm 371.66$ & 1268.74 \\
\hline 2 & $-1(20)$ & $0(20)$ & $-1(0.5)$ & $7789.40 \pm 940.94$ & 7634.11 & $3707.03 \pm 976.35$ & 3707.03 \\
\hline 3 & $1(50)$ & $0(20)$ & $-1(0.5)$ & $3039.69 \pm 253.69$ & 2895.15 & $1784.16 \pm 71.27$ & 1829.18 \\
\hline $4^{a}$ & $0(35)$ & $0(20)$ & $0(2.0)$ & $7433.20 \pm 346.14$ & 7588.00 & $2068.36 \pm 72.30$ & 1983.23 \\
\hline 5 & $1(50)$ & $1(35)$ & $0(2.0)$ & $7014.63 \pm 403.57$ & 7330.48 & $1949.60 \pm 108.82$ & 1904.58 \\
\hline 6 & $-1(20)$ & $-1(5)$ & $0(2.0)$ & $11457.13 \pm 126.47$ & 11572.09 & $1863.44 \pm 63.42$ & 1908.46 \\
\hline 7 & $-1(20)$ & $1(35)$ & $0(2.0)$ & $9855.10 \pm 250.64$ & 10324.65 & $1091.86 \pm 90.07$ & 1091.86 \\
\hline 8 & $0(35)$ & $1(35)$ & $1(3.5)$ & $4885.20 \pm 520.36$ & 4384.57 & $2720.93 \pm 328.90$ & 2765.95 \\
\hline 9 & $-1(20)$ & $0(20)$ & $1(3.5)$ & $5750.80 \pm 57.82$ & 5750.10 & $1383.31 \pm 7.21$ & 1338.29 \\
\hline 10 & $1(50)$ & $-1(5)$ & $0(2.0)$ & $7853.00 \pm 199.53$ & 8014.26 & $1227.05 \pm 57.92$ & 958.61 \\
\hline 11 & $1(50)$ & $0(20)$ & $1(3.5)$ & $3382.30 \pm 372.95$ & 3537.06 & $3079.00 \pm 27.82$ & 3079.00 \\
\hline 12 & $0(35)$ & $-1(5)$ & $-1(0.5)$ & $6332.60 \pm 737.33$ & 6171.24 & $3305.76 \pm 291.34$ & 3260.74 \\
\hline $13^{a}$ & $0(35)$ & $0(20)$ & $0(2.0)$ & $7442.50 \pm 874.25$ & 7588.00 & $1959.60 \pm 326.41$ & 1983.23 \\
\hline 14 & $0(35)$ & $1(35)$ & $-1(0.5)$ & $8318.70 \pm 517.16$ & 8002.76 & $1892.88 \pm 102.74$ & 1892.88 \\
\hline $15^{a}$ & $0(35)$ & $0(20)$ & $0(2.0)$ & $7889.10 \pm 183.51$ & 7588.00 & $1921.73 \pm 72.50$ & 1983.23 \\
\hline
\end{tabular}

${ }^{a}$ Central point. ${ }^{b}$ The best results obtained within the Box-Behnken design are highlighted in bold. 
Esterase Bacillus stearothermophilus - $10 \mathrm{~min}$ Esterase Bacillus stearothermophilus - 20 min

Esterase Saccharomyces cerevisiae - 10 min

Esterase Saccharomyces cerevisiae - 20 min
Esterase Bacillus subtilis - 10 min

$\square$ Esterase Bacillus subtilis - 20 min

Esterase Pseudomonas fluorescens - $10 \mathrm{~min}$

Esterase Pseudomonas fluorescens - 20 min
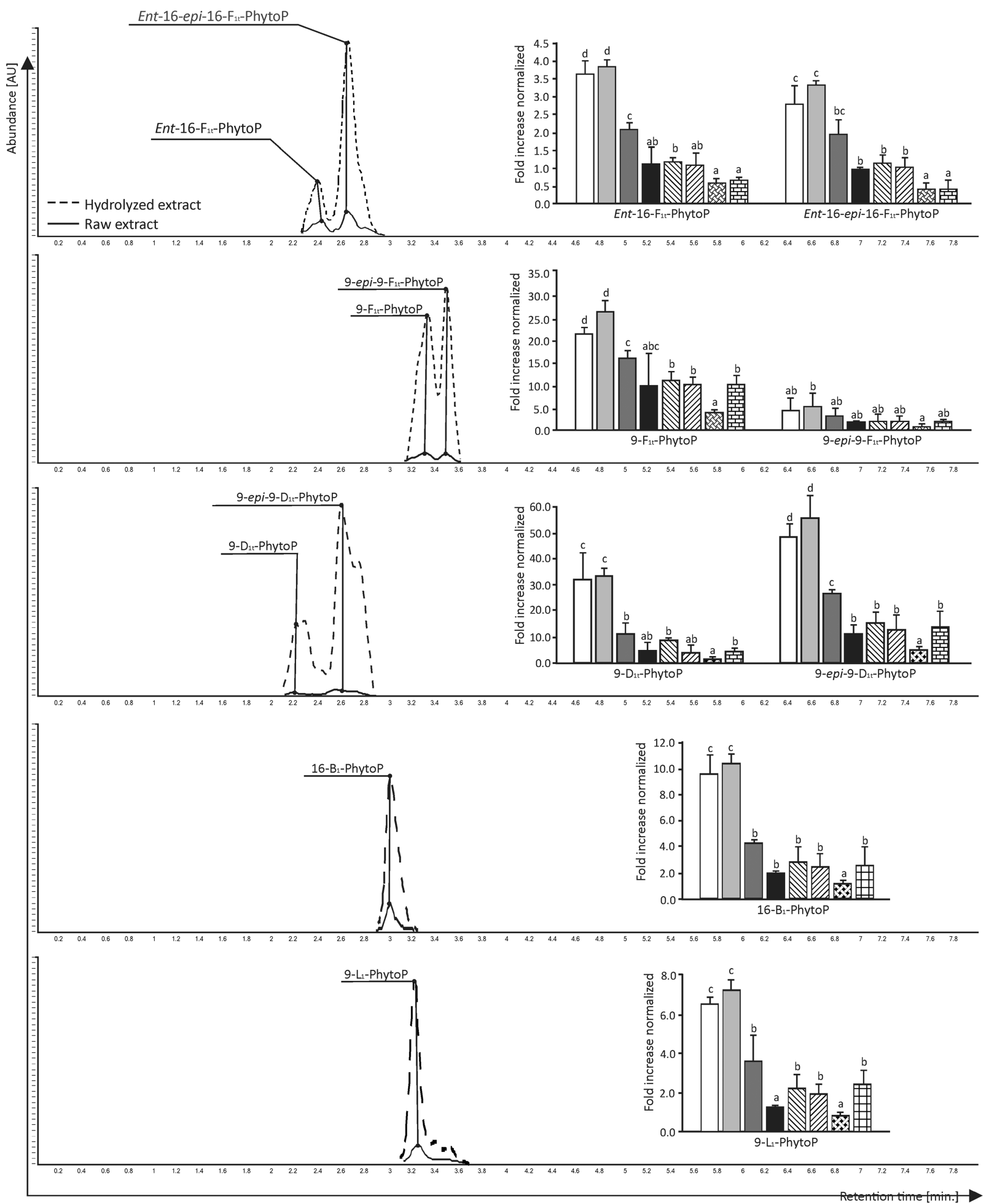

Figure 1. Percentage (mean \pm standard deviation, $S D)$ of the increase of free individual phytoprostanes $\left(9-\mathrm{F}_{1 \mathrm{t}}-\mathrm{PhytoP}\right.$, 9-epi-9- $\mathrm{F}_{1 \mathrm{t}}-\mathrm{PhytoP}$, ent-16-

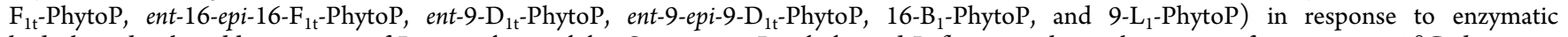
hydrolysis developed by esterases of B. stearothermophilus, S. cerevisiae, B. subtilis, and P. fluorescens by applying $1 \mu \mathrm{g}$ of enzyme, at $25{ }^{\circ} \mathrm{C}$, during 10 and $20 \mathrm{~min}$. Results were representative of three independent experiments. Statistical differences were identified according to the ANOVA and Tukey's multiple range test and set at $p<0.001$. Different lowercase letters indicate significantly different percentages. 


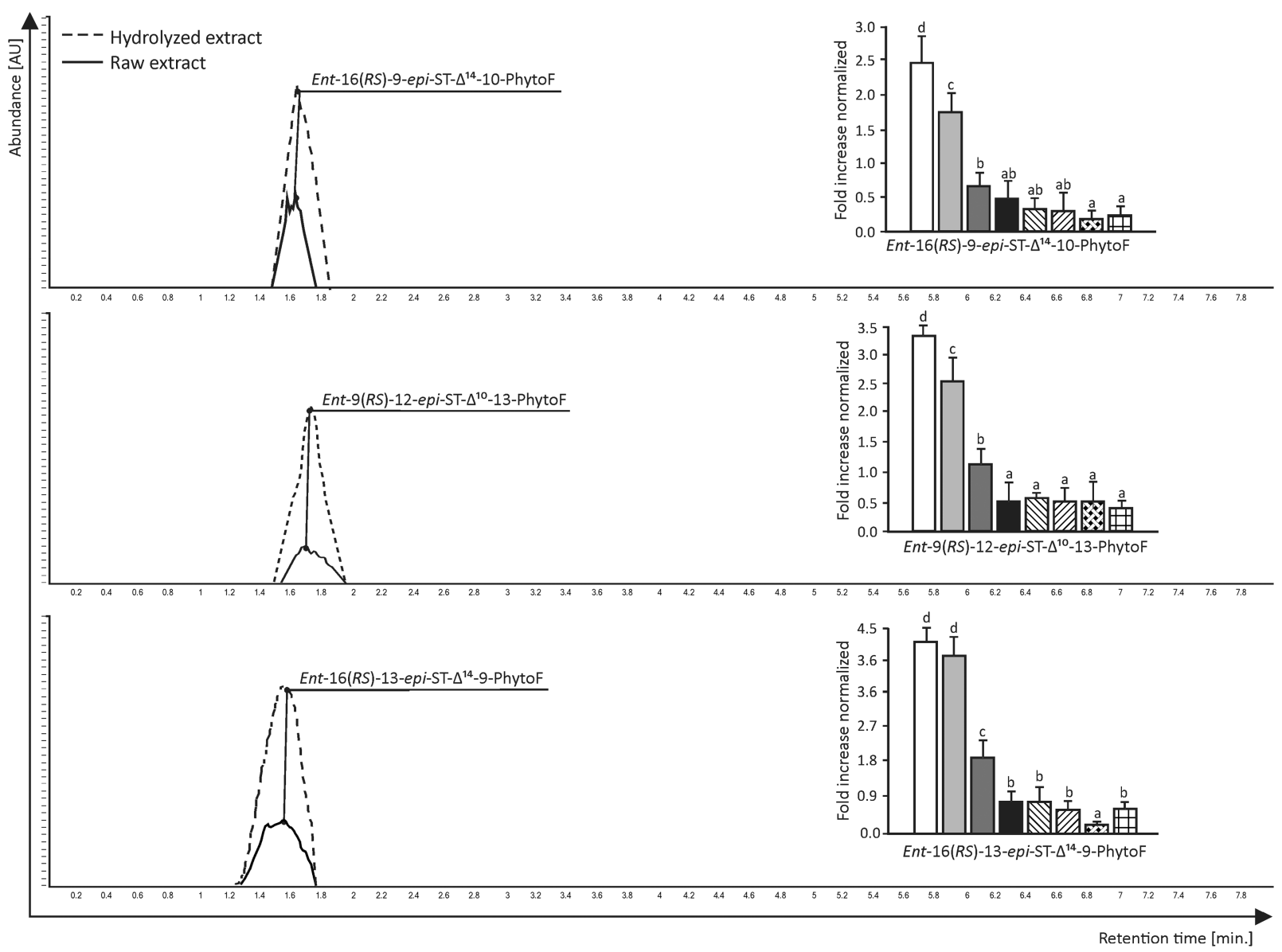

Figure 2. Percentage of increase of free individual phytofurans (ent-16(RS)-9-epi-ST- $\Delta^{14}-10$-PhytoF, ent-9(RS)-12-epi-ST- $\Delta^{10}-13-\mathrm{PhytoF}$, and ent16(RS)-13-epi-ST- $\Delta^{14}-9$-PhytoF) in response to enzymatic hydrolysis developed by esterases of $B$. stearothermophilus, S. cerevisiae, B. subtilis, and $P$. fluorescens by applying $1 \mu \mathrm{g}$ of enzyme, at $25{ }^{\circ} \mathrm{C}$, during 10 and $20 \mathrm{~min}$. Results are representative of three independent experiments. Statistical differences were identified according to the ANOVA and Tukey's multiple range test and set at $p<0.001$. Different lowercase letters indicate significantly different percentages.

on the food matrix, the optimized hydrolysis conditions achieved would be applicable to additional dietary sources of these compounds.

Preliminary Selection of Esterases. According to the selection criteria mentioned above, the relative efficiencies of the hydrolysis activity of the esterases produced by $B$. stearothermophilus, B. subtilis, and P. fluorescens, as well as by $S$. cerevisiae were assessed by applying the reaction conditions described in the Materials and Methods section $(1 \mu \mathrm{g}$ of enzyme per reaction, $25^{\circ} \mathrm{C}$, and 10 and $20 \mathrm{~min}$ reaction). The free PhytoPs and PhytoFs obtained as a result of the enzymatic hydrolysis were identified and quantified by UHPLC-ESIQqQ-MS/MS according to their molecular mass, specific fragmentation pattern, and elution order, in comparison with authentic standards.

When assessing hydrolyzed extracts for the concentration of free PhytoPs, it was found that the concentration of these compounds varied depending on the enzyme used to hydrolyze esterified compounds, the duration of the reaction, and the PhytoPs considered. In this respect, the results obtained revealed a significant augmentation of the concentration of PhytoPs belonging to the F-series (Figure 1). Presently, the hydrolysis by esterases from $B$. stearothermophilus, S. cerevisiae, and $B$. subtilis, as referred to a $20 \mathrm{~min}$ hydrolysis, which in general provided the most efficient reaction, gave rise to 3.8-, $1.1-$, and 1.1-fold higher values of free ent-16- $\mathrm{F}_{1 \mathrm{t}}-\mathrm{PhytoP}$, respectively, and 3.3-, 1.0-, and 1.0-fold higher values of free ent-16-epi-16- $\mathrm{F}_{1 \mathrm{t}}-\mathrm{PhytoP}$, respectively. On the other hand, the extracts hydrolyzed using esterases from $P$. fluorescens showed 0.7 - and 0.3 -fold lower contents of free ent-16- $\mathrm{F}_{1 \mathrm{t}}$-PhytoP and ent-16-epi- $\mathrm{F}_{1 \mathrm{t}}-\mathrm{PhytoP}$, on average, respectively. With respect to 9- $\mathrm{F}_{1 \mathrm{t}}$-PhytoP and 9-epi-9- $\mathrm{F}_{1 \mathrm{t}}-\mathrm{Phyto}$, the $20 \mathrm{~min}$ enzymatic hydrolysis developed using esterases from B. stearothermophilus, S. cerevisiae, B. subtilis, and P. fluorescens provided 26.1-, 9.8-, 10.1-, and 10.0-fold and 5.1-, 1.8-, 1.9-, and 1.9-fold increases, on average, respectively.

The enzymatic hydrolysis of PhytoPs belonging to the Dseries by esterases from B. stearothermophilus, S. cerevisiae, $B$. subtilis, and P. fluorescens resulted in 33.3-, 4.4-, 3.6-, and 4.3fold and 55.5-, 11.0-, 12.5-, and 13.7-fold higher concen- 
trations, on average, for 9- $\mathrm{D}_{1 \mathrm{t}}$-PhytoP and 9-epi-9- $\mathrm{D}_{1 \mathrm{t}}$-PhytoP, respectively (Figure 1).

At last, 16- $\mathrm{B}_{1}$ - and 9- $\mathrm{L}_{1}$-PhytoP experienced an average of 10.3-, 1.9-, 2.4-, and 2.5-fold and 7.3-, 1.3-, 1.9-, and 2.4-fold increases, respectively, for the above-referred esterases (Figure $1)$.

Beyond the PhytoPs, the quantification of PhytoFs in the hydrolyzed extracts also revealed increased concentrations of the free compounds, while the size of the augmentation was closely dependent on the enzyme, the duration of the hydrolysis reaction, and the PhytoF considered (Figure 2). Thus, after a $20 \mathrm{~min}$ reaction, the concentrations of free PhytoFs provided by the esterases of B. stearothermophilus, $S$. cerevisiae, B. subtilis, and $P$. fluorescens, regarding ent-16-(RS)-9epi-ST- $\Delta^{14}$-10-PhytoF, were 2.1-, 0.6-, 0.4-, and 0.3-fold higher, on average, respectively, relative to nonhydrolyzed extracts, while for ent-9-(RS)-12-epi-ST- $\Delta^{10}-13$-PhytoF, the increase observed was 3.0-, 0.9-, 0.8-, and 0.6-fold, respectively. At last, the hydrolysis reactions provided concentrations of ent-16$(R S)$-13-epi-ST- $\Delta^{14}-9-$ PhytoF increased by 3.6-, 1.3-, $0.9-$-, and 0.6-folds, respectively (Figure 2 ).

The results obtained on the advantage of the application of enzymatic hydrolysis for determining the concentration of total PhytoPs and PhytoFs are difficult to compare with previous data from the bibliography because of the lack of previous reports on the efficiency of esterases regarding the hydrolysis of oxylipins. In addition, when applying alkaline hydrolysis to PhytoP and PhytoF extracts to obtain free compounds, no comparison with nonhydrolyzed extracts was provided. ${ }^{15}$ Within this frame, there has been a recent and growing interest in applying enzymatic methods. ${ }^{17}$ Thus, although there is no information on the benefits of these procedures on the quantification of free PhytoPs and PhytoFs to date, previous reports on the analysis of mammal oxylipins (isoprostanes and prostaglandins) have resulted in successfully enzymatic hydrolysis methods for the evaluation of the whole compounds (free and esterified with glucuronic acid). ${ }^{34}$ An increase of the concentration of free compounds in a study on neuroprostanes and dihomo-isoprostanes in 15 volunteers ranged between 2and 31-folds depending on the individual compound considered. ${ }^{35}$ These reports support the interest in developing such hydrolysis methods for the assessment of PhytoPs and PhytoFs in plant-based foods, which is further reinforced by the results presented in the present work, which evidence the interest in applying esterases capable of cleaving ester bonds, without the requirement of cofactors, ${ }^{36}$ which turns them into attractive biocatalysts, while the low production cost makes the use of esterases a feasible alternative for industrial applications. $^{37}$

When analyzing the influence of the diverse hydrolysis incubation times on the final efficiency of the reactions in terms of obtaining free compounds, it was noticed that the most efficient hydrolysis was obtained after a 10 or 20 min reaction depending on the enzyme and family of compounds considered. Thus, for PhytoPs, no significant differences were found between the reaction times for enzymes from $B$. stearothermophilus and B. subtilis and esterases from S. cerevisiae and $P$. fluorescens were more efficient at 10 and $20 \mathrm{~min}$, respectively. On the other hand, with respect to PhytoFs, it was observed that esterases of B. stearothermophilus and S. cerevisiae provided a lower concentration of free compounds after a 20 min reaction and the results upon hydrolysis catalyzed by $B$. subtilis were not significantly different between 10 and $20 \mathrm{~min}$.
This was also observed for $P$. fluorescens esterases, except for ent-16-(RS)-13-epi-ST- $\Delta^{14}$-9-PhytoF, whose concentrations were significantly higher in reactions lasting $20 \mathrm{~min}$ (Figures 1 and 2). In the case of lower yield as a result of longer hydrolysis reactions, this could be due to a further degradation of free PhytoPs and PhytoFs, although this situation should be confirmed by analyzing the formation of secondary compounds. In this regard, previous reports have described that incubation times longer than $30 \mathrm{~min}$ could be related to nonspecific granulation that would compromise the precision of the hydrolysis reactions. ${ }^{38}$ In this respect, the possibility should be explored that PhytoPs and PhytoFs could react and/ or aggregate and, thus, precipitate together with enzymes responsible for the hydrolysis reactions that could, to some extent, explain the decrease of free molecules when increasing the hydrolysis reaction time. These incubation times were further fine-tuned by applying the RSM model.

In light of these findings, the esterase from B. stearothermophilus was selected as the most efficient, and the subject of the further optimization of the factors such as reaction time, temperature, and enzyme concentration, which are directly involved in the enzymatic activity. ${ }^{22,23}$

For the optimization of these factors, a Box-Behnken/ response surface methodology (RSM) design was developed, which was chosen based on its efficiency, according to recent publications. ${ }^{39}$ Upon the research reported by Ferreira et al., ${ }^{39}$ a Box-Behnken design was compared with other response surface designs (central composite, Doehlert matrix, and threelevel full factorial design), demonstrating that the BoxBehnken and Doehlert matrix designs are more efficient than the central composite design and the three-level full factorial designs. Thus, the three-level full factorial design is consistent with a number of factors higher than 2 .

Optimization of Enzymatic Hydrolysis of Phytoprostanes and Phytofurans. The levels considered for the factors influencing the hydrolysis of PhytoP and PhytoF esters were established according to the information available in the literature, ${ }^{28,40-42}$ together with preliminary results achieved during the selection of the most efficient esterase. Thus, ranges of values considered for the variables optimized ( $X_{1}$ (temperature), $X_{2}$ (time), and $X_{3}$ (enzyme concentration)) were 20$50{ }^{\circ} \mathrm{C}, 5-35 \mathrm{~min}$, and $0.5-3.5 \mu \mathrm{g}$, respectively (Table 2 ). These ranges were considered symmetrical according to the characteristics of the "central point" Box-Behnken design. ${ }^{43}$ The results obtained from the array of hydrolysis conditions tested indicated that the optimal conditions differed when considering the optimal yield of total PhytoPs or PhytoFs. Hence, while the most efficient hydrolysis of PhytoP esters, expressed as the concentration of total free PhytoPs, was achieved when developing the enzymatic hydrolysis at $20{ }^{\circ} \mathrm{C}$ for $5 \mathrm{~min}$ using $2.0 \mu \mathrm{g}$ of enzyme per reaction $(11457.13 \mu \mathrm{g} / \mathrm{kg}$ $\mathrm{dw}$, on average), the best hydrolysis of PhytoF esters, expressed as the concentration of total free PhytoFs, was achieved at $20{ }^{\circ} \mathrm{C}$ for $20 \mathrm{~min}$ using $0.5 \mu \mathrm{g}$ of enzyme per reaction conditions $(3707.03 \mu \mathrm{g} / \mathrm{kg} \mathrm{dw}$, on average) (Table 2).

Experimental Design Optimization and Model Building. The sets of results obtained through the implementation of the experimental design provided in Table 2 were modeled to obtain the experimental values for the three variables considered, providing the maximum concentrations of total nonesterified PhytoPs and PhytoFs. In this respect, the implementation of the design and the processing of the results allowed obtaining the reduced model equations that permitted 
Table 3. Corresponding $f$-Values and $p$-Values for Each Obtained Coefficient and Second-Order Polynomial Models Used To Express the Content $(\mu \mathrm{g} / \mathrm{kg} \mathrm{dw})$ of Individual and Total Phytoprostanes and Phytofurans in Pisum sativum L. ${ }^{a}$

\begin{tabular}{|c|c|c|c|c|c|c|c|c|c|c|}
\hline variable & statistics & $X_{1}$ & $X_{2}$ & $X_{3}$ & $X_{1,2}$ & $X_{1,3}$ & $X_{2,3}$ & $X_{1}^{2}$ & $X_{2}^{2}$ & $X_{3}^{2}$ \\
\hline \multirow[t]{2}{*}{ total PhytoPs } & $p$-value & N.S. & N.S. & $* *$ & N.S. & $* *$ & $* * *$ & $*$ & $* *$ & $* *$ \\
\hline & $f$-value & 0.71 & 0.35 & 47.44 & 9.48 & 42.04 & 413.49 & 30.5 & 111.09 & 159.23 \\
\hline \multirow[t]{2}{*}{ total PhytoFs } & $p$-value & $* *$ & * & N.S. & N.S. & N.S. & N.S. & $* *$ & $* *$ & $* *$ \\
\hline & $f$-value & 151.44 & 161.05 & 3.23 & 1.90 & 2.00 & 6.78 & 65.73 & 40.00 & 161.31 \\
\hline \multicolumn{9}{|c|}{ polynomial models ${ }^{c}$} & $R^{2}$ & $\mathrm{MAE}^{b}$ \\
\hline \multicolumn{9}{|c|}{$\begin{array}{l}\text { total phytoprostanes }=7588.27-1713.44 X_{1}-557.808 X_{2}-335.525 X_{3}-303.176 X_{1}^{2}+215.915 X_{1} X_{2}+606.483 X_{1} X_{3}+ \\
1784.87 X_{2}^{2}-1784.87 X_{2} X_{3}-2305.72 X_{3}^{2}\end{array}$} & 0.994 & 117.628 \\
\hline \multicolumn{11}{|c|}{ total phytofurans $=1983.23-34.2833 * X_{1}+32.34 * X_{2}-279.732 * X_{3}-163.027 * X_{1}^{2}+440.642 * X_{1} * X_{2}+904.64 * X_{1} * X_{3}-$} \\
\hline
\end{tabular}

$354.325 * X_{2}^{2}+716.268 * X_{2}^{*} X_{3}+668.172 * X_{3}^{2}$

${ }^{a}$ N.S., not significant; significant at $*^{*}<0.05$, ${ }^{*} p<0.01$, and $* * * p<0.001 .{ }^{b} \mathrm{MAE}$, mean absolute error. ${ }^{c} X_{1}$, temperature $\left({ }^{\circ} \mathrm{C}\right)$; $X_{2}$, time $(\mathrm{min})$; and $X_{3}$, enzyme $(\mu \mathrm{g})$.
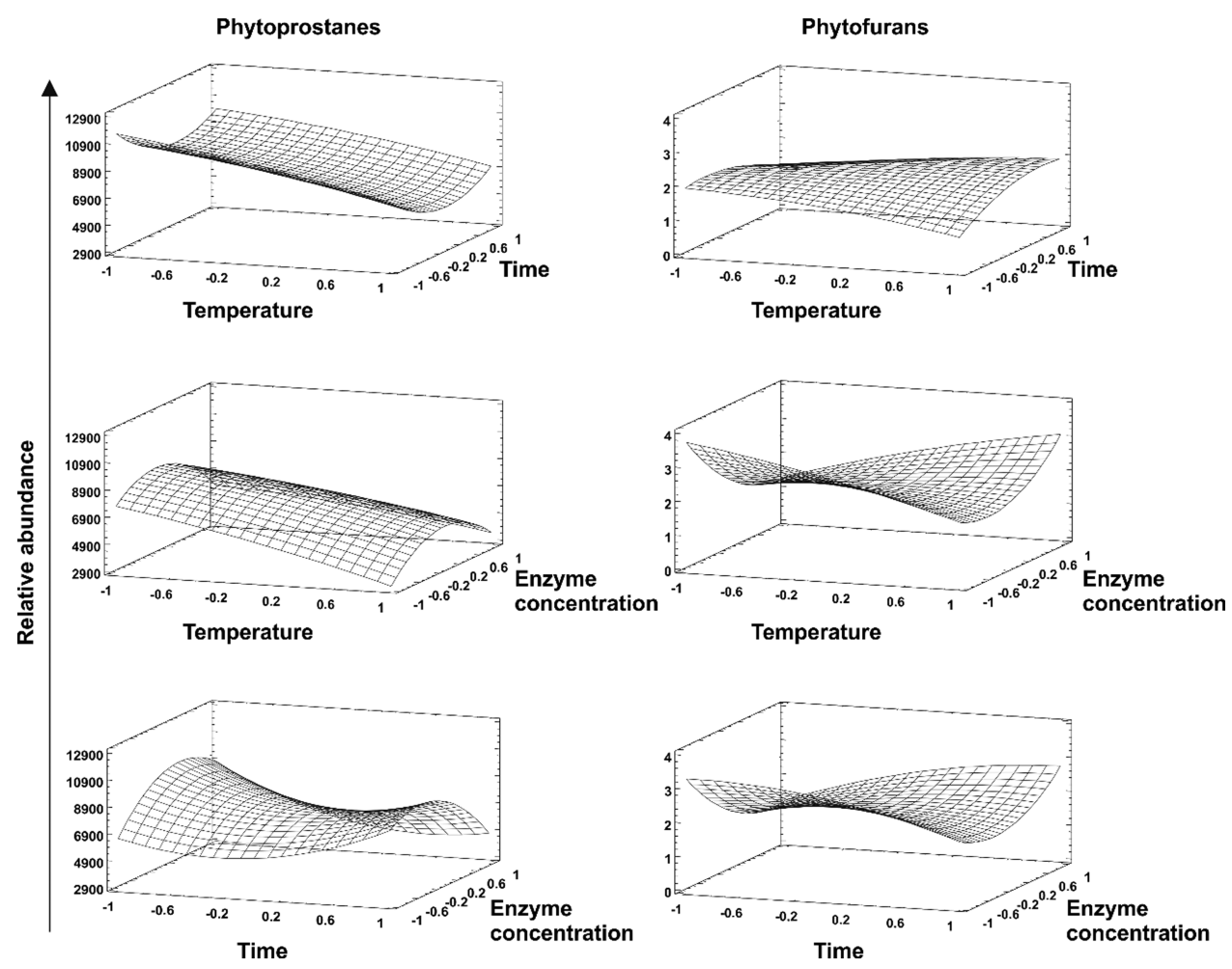

Figure 3. Response surface plots showing the effect of time, temperature, and enzyme concentration on the hydrolysis of esters from phytoprostanes and phytofurans toward total free compounds. Units of axes $x$ and $z$ are according to the information provided in Table 2.

the calculation of the theoretical values of total free PhytoPs (total PhytoPs $=7588.27-1713.44 X_{1}-557.808 X_{2}-$ $335.525 X_{3}-303.176 X_{1}^{2}+215.915 X_{1} X_{2}+606.483 X_{1} X_{3}+$ $1784.87 X_{2}^{2}-1784.87 X_{2} X_{3}-2305.72 X_{3}^{2}$ ) and PhytoFs (total PhytoFs $=1983.23-34.2833 * X_{1}+32.34 * X_{2}-279.732 * X_{3}-$ $163.027 * X_{1}^{2}+440.642 * X_{1} * X_{2}+904.64 * X_{1} * X_{3}-$ $\left.354.325 * X_{2}^{2}+716.268 * X_{2} * X_{3}+668.172 * X_{3}^{2}\right)$ upon diverse combinations of temperature, time, and enzyme concentration (Table 3).

According to these equations, the extraction of total nonesterified PhytoPs by enzymatic hydrolysis catalyzed by esterases from B. stearothermophilus is closely dependent on the simple and quadratic effect of the enzyme concentration (both at a $p<0.01$ significant level), as well as on the quadratic effect of the temperature $(p<0.05)$ and extraction time $(p<0.01)$ utilized. The efficiency of the extraction of nonesterified PhytoPs was also significantly influenced by the interactions between temperature and enzyme concentration $(p<0.05)$ and between reaction time and enzyme concentration $(p<$ 0.01 ) (Table 3 ). When analyzing the model by means of the " $f$ " statistical test with analysis of variance (ANOVA) to evaluate the goodness of fit, a value of 16.527 , with a very low probability value $(p<0.001)$, was obtained, providing information on a high degree of significance. ${ }^{44}$ Also, the model obtained was verified in regard to its efficiency for obtaining the highest concentration of total nonesterified PhytoPs, in agreement with the coefficient of determination $\left(R^{2}=0.994\right)$ (Table 3$)$, which indicated that $99.4 \%$ of all variations were explained by the model. ${ }^{44}$

The analysis of the model indicators regarding PhytoFs revealed that the enzymatic hydrolysis of esterified PhytoFs catalyzed by esterases from $B$. stearothermophilus depended on the simple and quadratic effect of the temperature (both at $p<$ 0.01 significant level) and incubation time of the hydrolysis reaction ( $p<0.05$ and $p<0.01$, respectively), as well as on the quadratic effect of the enzyme concentration $(p<0.01)$, while 
no interaction between factors was found (Table 3). Regarding PhytoFs, the evaluation of the $f$ statistical indicator provided a value of 25.938 , with a probability value set at $p<0.01$, again informed on the high degree of significance. ${ }^{44}$ Also, the verification of the model achieved with respect to its efficiency for the calculation of the yield of total nonesterified PhytoFs through the calculation of the coefficient of determination $\left(R^{2}\right)$ revealed a value of 0.996 , indicating that $99.6 \%$ of all variations were explained by the model. ${ }^{44}$

Relevance of the Processing Variables Considered and Their First-Order Interaction. In agreement with the results obtained in the present work, it was observed that temperature, time, and concentration of esterases were critical factors for achieving the optimal hydrolysis of PhytoP and PhytoF esters for obtaining free compounds. Indeed, based on the reduced model equations, it was confirmed that the efficiency of the hydrolysis of PhytoP and PhytoF esters by the esterase from $B$. stearothermophilus was closely dependent on the range of values considered for these factors. However, contrary to previous reports that indicated that the enzyme concentration was the most relevant factor for enzymatic hydrolysis, ${ }^{45}$ the present results obtained evidenced a highly significant interaction of the enzyme concentration with the temperature and the duration of the reaction for PhytoPs. As for PhytoFs, the contribution of temperature and time of reaction was significantly related to the efficiency of the hydrolysis, while no significant influence was detected for the enzyme concentration, which was considered to be linear. These results could be influenced by the fact that after an initial rapid phase the rate of hydrolysis decreased independently of the enzyme concentration, perhaps due to the esterified substrate available for hydrolysis being lower, thus becoming a limiting factor. ${ }^{46}$ Alternatively, it has been suggested that the formation of hydrolysis products could limit the enzymatic activity. ${ }^{47}$

Apart from the enzyme concentration, with respect to temperature, previously reported results suggest that enzymatic hydrolysis increases together with the increase in temperature. ${ }^{48}$ However, this was not observed when monitoring the optimal temperature for the hydrolysis of esters from PhytoPs and PhytoFs. The evolution of the concentration of free PhytoPs and PhytoFs may suggest, to some extent, an eventual denaturalization of enzymes in parallel to the increase in temperature, indicating a lower hydrolysis efficiency at high temperatures. $^{46}$

The response surface plots in Figure 3 represent a practical manner of visualizing the first-order interactions between the diverse combinations of two factors, when the additional variable in the system is in its middle level. Hence, the representation of such interactions confirms the significance of the interactions between enzyme concentration with incubation time and temperature, in regard to the concentration of free PhytoPs in the extracts (Figure 3).

Validation of the Optimal Conditions Retrieved. The validation of the models developed in the present work was done by applying the optimal hydrolysis conditions provided by the model for the esterase from $B$. stearothermophilus. Interestingly, in this respect, the analysis of the results obtained provided the optimal conditions for nonesterified PhytoPs $\left(21.5^{\circ} \mathrm{C}, 5.7 \mathrm{~min}\right.$, and $0.61 \mu \mathrm{g}$ of enzyme per reaction) and nonesterified PhytoFs $\left(20.0^{\circ} \mathrm{C}, 5.0 \mathrm{~min}\right.$, and $2.17 \mu \mathrm{g}$ of enzyme per reaction) (Figure 4 ).
No hydrolyzed $\square$ Alkaline hydrolysis

Theoretical values obtained applying phytoprostanes optimal extraction model

Theoretical values obtained applying phytofurans optimal extraction model

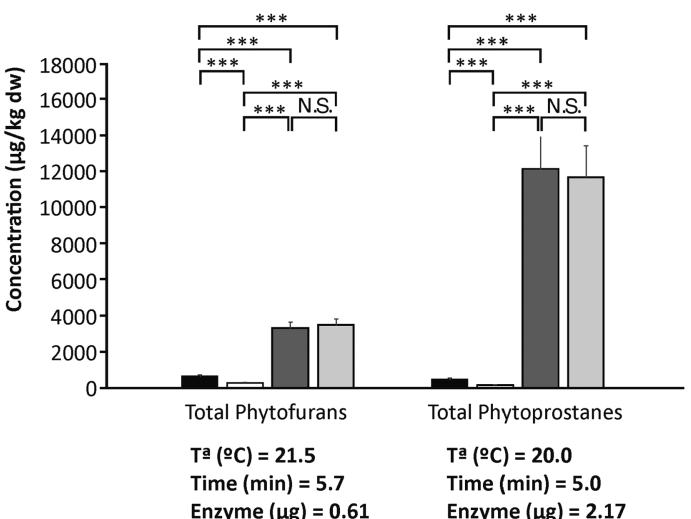

Figure 4. Concentration of total nonesterified phytoprostanes and phytofurans in pea ( $P$. sativum L.), concentration after alkaline hydrolysis, and theoretical and observed values under optimum hydrolysis conditions based on individual response corresponding to total phytofurans and phytoprostanes $(\mu \mathrm{g} / \mathrm{kg} \mathrm{dw})$. Statistical differences were identified according to the ANOVA and Tukey's multiple range test and set at $p<0.001(* * *)$. N.S. $=$ no significant differences.

According to the optimal hydrolysis conditions, the predicted yield of nonesterified PhytoPs was $11774.10 \mu \mathrm{g} / \mathrm{kg}$ dw. This was validated through three hydrolysis reactions developed by applying the optimal conditions that yielded, on average, $11657.13 \mu \mathrm{g} / \mathrm{kg}$, which was not significantly different from the theoretical value (Figure 4). In addition, a comparison of the optimal hydrolysis conditions on esters from PhytoFs gave rise to an experimental yield of $3707.58 \mu \mathrm{g}$ of nonesterified PhytoFs per $\mathrm{kg}$ of $P$. sativum, which was not significantly different from the theoretical value predicted by the model $(3477.36 \mu \mathrm{g} / \mathrm{kg} \mathrm{dw})$. Thus, according to these matches, enzyme-assisted hydrolysis of esters from PhytoPs and PhytoFs was demonstrated to be highly efficient and specific. In addition, the enzymatic hydrolysis also provided significantly higher concentrations of total PhytoPs and PhytoFs than the alkaline hydrolysis applied previously for the evaluation of these plant oxylipins ${ }^{15}$ (59.00 and $280.00 \mu \mathrm{g}$ / $\mathrm{kg} \mathrm{dw}$, respectively). As stated before, the lower effectiveness of the alkaline hydrolysis, which even caused a significant decrease in the concentration of the compounds of interest, relative to the results of the hydrolytic activity of the $B$. stearothermophilus esterases could be due to the impact of the alkaline reaction conditions on the stability of esterified and nonesterified PhytoPs and PhytoFs. ${ }^{16}$

Therefore, to understand the impact of the optimal hydrolysis conditions retrieved for PhytoPs on PhytoFs and vice versa, the concentrations of individual free PhytoPs and PhytoFs were monitored when applying both hydrolysis conditions (Figure 5). Upon this measurement, it was observed that both hydrolysis conditions provided similar concentrations of most individual PhytoPs and PhytoFs, except for ent-16-(RS)-9-epi-ST- $\Delta^{14}$-10-PhytoF, ent-9-(RS)-12-epi-ST$\Delta^{10}-13$-PhytoF, and $16-\mathrm{B}_{1}-\mathrm{PhytoP}$, as these had significantly higher concentrations as a result of hydrolysis reactions developed when applying the specific conditions provided by the model for their specific class of oxylipins (Figure 5). In 
- - Optimal enzyme hydrolysis conditions for total phytofurans $(T \underline{T}(\stackrel{\circ}{ } \mathrm{C})=21.5 ;$ Time $(\min )=5.7 ; ;$ Enzyme $(\mu \mathrm{g})=0.61)$

- Optimal enzyme hydrolysis conditions for total phytoprostanes $\left(\mathrm{T}^{\mathrm{a}}(\stackrel{\circ}{ } \mathrm{C})=20.0\right.$; Time $(\mathrm{min})=5.0$; Enzyme $\left.(\mu \mathrm{g})=2.17\right)$

- Alkaline hydrolysis

Ent-16-(RS)-9-epi-ST- $\Delta^{14}-10-$ PhytoF

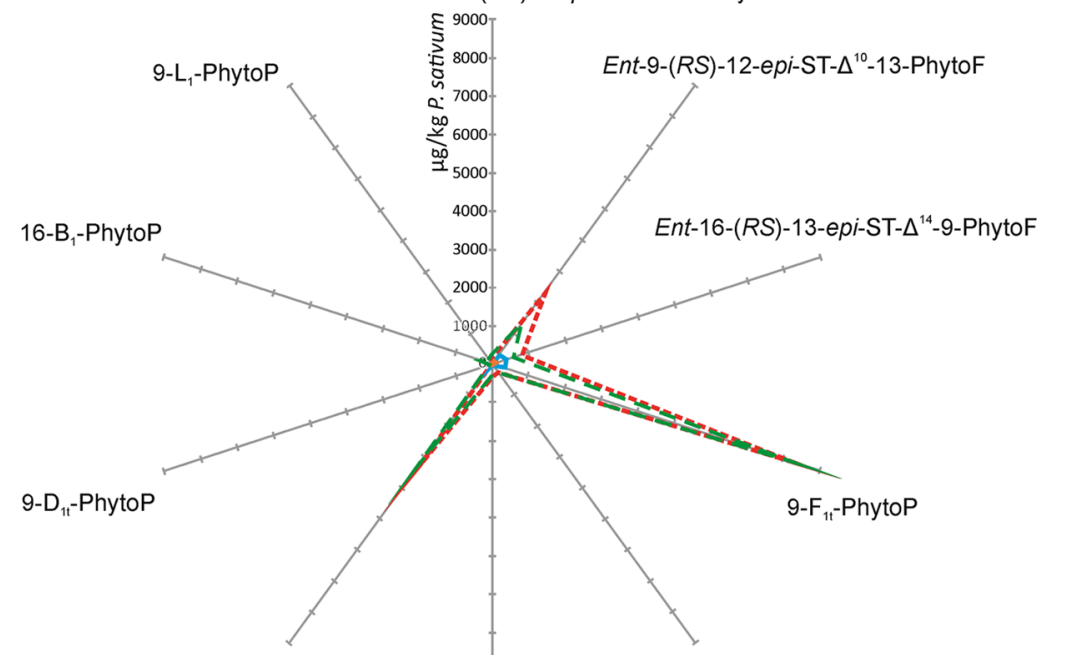

9-epi-9-D ${ }_{1 t}-$ PhytoP

Ent-16- $\mathrm{F}_{1 \mathrm{t}}-\mathrm{PhytoP}+$ Ent-16-epi-16- $\mathrm{F}_{1 \mathrm{t}}-\mathrm{PhytoP}$

9-epi- $\mathrm{F}_{1 \mathrm{t}}$-PhytoP

\begin{tabular}{|c|c|c|c|c|c|c|}
\hline & \multirow{2}{*}{ Non-hydrolyzed } & \multirow{2}{*}{ Alkaline hydrolysis } & \multicolumn{2}{|c|}{ Optimal hydrolysis conditions for } & \multirow{2}{*}{ Significance } & \multirow{2}{*}{ LSD $(p$-value $<0,05)$} \\
\hline & & & Phytofurans & Phytoprostanes & & \\
\hline Ent-16-(RS)-9-epi-ST- $\Delta^{14}-10-$ PhytoF & $26.0 \mathrm{c}$ & $10.0 \mathrm{~d}$ & $250.9 \mathrm{a}$ & $181.8 \mathrm{~b}$ & $p<0.01$ & 6.3 \\
\hline Ent-9-(RS)-12-epi-ST- $\Delta^{10}-13-$ PhytoF & $268.5 c$ & $120 \mathrm{~d}$ & $1320.0 \mathrm{~b}$ & $2416.6 a$ & $p<0.001$ & 26.3 \\
\hline Ent-16-(RS)-13-epi-ST- $\Delta^{1-}-9-$ PhytoF & $351.6 \mathrm{c}$ & $150.0 \mathrm{~d}$ & $599.0 \mathrm{~b}$ & $878.9 \mathrm{a}$ & $p<0.01$ & 71.3 \\
\hline 9-F $\mathrm{F}_{10}$-PhytoP & $312.7 c$ & $0.0 \mathrm{~d}$ & $8206.9 \mathrm{a}$ & $7816.1 \mathrm{~b}$ & $p<0.001$ & 74.5 \\
\hline Ent-16-F $\mathrm{F}_{1 \mathrm{t}}$-PhytoP + Ent-16-epi-16- $\mathrm{F}_{1 \mathrm{t}}$-PhytoP & $73.0 \mathrm{c}$ & $36.0 c$ & $250.4 a$ & $255.5 \mathrm{a}$ & $p<0.01$ & 19.5 \\
\hline 9-epi-F1t-PhytoP & $11.3 \mathrm{~b}$ & $0.0 \mathrm{c}$ & $311.9 \mathrm{a}$ & $339.1 \mathrm{a}$ & $p<0.01$ & 58.6 \\
\hline 9-epi-9-D $\mathrm{D}_{1 \mathrm{t}}$-PhytoP & $63.5 \mathrm{~b}$ & $23.0 \mathrm{~b}$ & $3272.2 \mathrm{a}$ & $3176.9 \mathrm{a}$ & $p<0.05$ & 41.8 \\
\hline 9-D1t-PhytoP & $1.4 \mathrm{~b}$ & $0.0 \mathrm{~b}$ & $45.7 \mathrm{a}$ & $40.8 \mathrm{a}$ & $p<0.01$ & 2.5 \\
\hline 16-B-B - PhytoP & $1.2 \mathrm{c}$ & $0.0 \mathrm{c}$ & $312.7 \mathrm{a}$ & $11.7 \mathrm{~b}$ & $p<0.01$ & 1.1 \\
\hline 9-L $\mathrm{L}_{1}$-PhytoP & $0.5 \mathrm{c}$ & $0.0 \mathrm{c}$ & $138.9 \mathrm{a}$ & $15.4 \mathrm{~b}$ & $p<0.01$ & 0.4 \\
\hline
\end{tabular}

Figure 5. Descriptive analysis of the profile and concentration of individual phytoprostanes and phytofurans ( $\mu \mathrm{g} / \mathrm{kg} \mathrm{dw})$ of pea (P. sativum L.) crude extracts, and extracts processed applying alkaline hydrolysis, and the optimal enzyme hydrolysis conditions recorded for total phytofurans and phytoprostanes. (blue line) Unhydrolyzed extracts, (double red hypen) values provided by enzymatic hydrolysis applying the optimal conditions for phytofurans, (double green hypen), values provided by enzymatic hydrolysis applying the optimal conditions for phytoprostanes, and (yellow line) alkaline hydrolysis. The concentrations $(\mu \mathrm{g} / \mathrm{kg} \mathrm{dw})$ of individual phytoprostanes and phytofurans are provided in the table at the bottom of the figure. Statistical differences were identified according to the ANOVA and Tukey's multiple range test. Different lowercase letters in the same row indicate significantly different concentrations.

addition, the concentration obtained by enzymatic hydrolysis was significantly higher in comparison with the concentration found when utilizing alkaline hydrolysis (Figure 5), regarding both individual PhytoPs and PhytoFs, confirming the findings reported on total free compounds.

In conclusion, the hydrolysis of the esterified forms of PhytoPs and PhytoFs by the use of bacterial and yeast esterases, which was optimized in the present work through the use of an RSM model using a Box-Behnken design, constitutes a valuable alternative for obtaining free, nonesterified, compounds, well-fitting with the currently available array of standards. According to this, the quantitative determination of these compounds in plant extracts, hydrolyzed as per the model developed and described in the present work, will be more accurate, thus avoiding unspecific reactions that could be tentatively occurring when applying chemical hydrolysis and that could be related with underestimations of the actual concentrations of these compounds in the analyzed extracts. In addition, the implementation of this hydrolysis method will provide a valuable tool for the successful assessment of the specific esterified forms of PhytoPs and
PhytoFs when applying jointly with untargeted metabolomic approaches to both intact and hydrolyzed extracts of the plant material. In this regard, the application of this environmentally friendly hydrolysis alternative will allow obtaining significantly higher concentrations of nonesterified compounds in the extracts, which is essential for the practical application of this metabolomic approach.

\section{AUTHOR INFORMATION}

\section{Corresponding Author}

A. Gil-Izquierdo - Research Group on Quality, Safety, and Bioactivity of Plant Foods, Department of Food Science and Technology, (CEBAS-CSIC), University Campus of Espinardo, Edif. 25, 30100 Murcia, Spain; Phone: +34968396200;

Email: angelgil@cebas.csic.com

\section{Authors}

R. Domínguez-Perles - Research Group on Quality, Safety, and Bioactivity of Plant Foods, Department of Food Science and Technology, (CEBAS-CSIC), University Campus of Espinardo, Edif. 25, 30100 Murcia, Spain; (1) orcid.org/0000-0001$6232-712 \mathrm{X}$ 
I. Sánchez-Martínez - Research Group on Quality, Safety, and Bioactivity of Plant Foods, Department of Food Science and Technology, (CEBAS-CSIC), University Campus of Espinardo, Edif. 25, 30100 Murcia, Spain

M. D. Rodríguez-Hernández - Research Group on Quality, Safety, and Bioactivity of Plant Foods, Department of Food Science and Technology, (CEBAS-CSIC), University Campus of Espinardo, Edif. 25, 30100 Murcia, Spain

I. López-González - Research Group on Quality, Safety, and Bioactivity of Plant Foods, Department of Food Science and Technology, (CEBAS-CSIC), University Campus of Espinardo, Edif. 25, 30100 Murcia, Spain

C. Oger - Institut des Biomolecules Max Mousseron, IBMM, UMR 5247, University of Montpellier, CNRS, ENSCM, 34090 Montpellier, France; O orcid.org/0000-0002-5177-5792

A. Guy - Institut des Biomolecules Max Mousseron, IBMM, UMR 5247, University of Montpellier, CNRS, ENSCM, 34090 Montpellier, France

T. Durand - Institut des Biomolecules Max Mousseron, IBMM, UMR 5247, University of Montpellier, CNRS, ENSCM, 34090 Montpellier, France

J. M. Galano - Institut des Biomolecules Max Mousseron, IBMM, UMR 5247, University of Montpellier, CNRS, ENSCM, 34090 Montpellier, France

F. Ferreres - Research Group on Quality, Safety, and Bioactivity of Plant Foods, Department of Food Science and Technology, (CEBAS-CSIC), University Campus of Espinardo, Edif. 25, 30100 Murcia, Spain

Complete contact information is available at:

https://pubs.acs.org/10.1021/acs.jafc.9b06624

\section{Author Contributions}

${ }^{\S}$ R.D.-P. and I.S.-M. contributed equally to the present work.

\section{Funding}

This work was partially funded by the "Fundación Séneca de la Región de Murcia” Grupo de Excelencia 19900/GERM/15 and the Spanish project AGL2017-83386-R from the Spanish Ministry of Science, Innovation and Universities. This work is included within the framework of the collaboration between the Spanish Research Council (CEBAS-CSIC) and CNRS by "Projets Internationaux de Cooperation Scientifique (PICS2015-261141)". RDP was sponsored by a Postdoctoral Contract (Juan de la Cierva de Incorporación ICJI-201525373) from the Ministry of Economy, Industry and Competitiveness of Spain. The authors thank the English expert reviewer (Mario G. Fon, MS) for the revision of the English style and grammar.

\section{Notes}

The authors declare no competing financial interest.

\section{ABBREVIATIONS}

AA, arachidonic acid; ALA, $\alpha$-linolenic acid; BHA, butylated hydroxy anisole; PhytoPs, phytoprostanes; PhytoFs, phytofurans; ROS, reactive oxygen species; SPE, solid-phase extraction; UHPLC-ESI-QqQ-MS/MS, ultrahigh-performance liquid chromatography coupled to electrospray ionization and triple quadrupole mass spectrometry

\section{REFERENCES}

(1) Ferreres, F.; Grosso, C.; Gil-Izquierdo, A.; Valentao, P.; Andrade, P. B. Ellagic acid and derivatives from Cochlospermum angolensis Welw. Extracts: HPLC-DAD-ESI/MS(n) profiling, quantification and in vitro anti-depressant, anti-cholinesterase and anti-oxidant activities. Phytochem. Anal. 2013, 24, 534-540.

(2) Moita, E.; Gil-Izquierdo, A.; Sousa, C.; Ferreres, F.; Silva, L. R.; Valentao, P.; Dominguez-Perles, R.; Baenas, N.; Andrade, P. B. Integrated analysis of COX-2 and iNOS derived inflammatory mediators in LPS-stimulated RAW macrophages pre-exposed to Echium plantagineum L. bee pollen extract. PLoS One 2013, 8, No. e59131.

(3) Weaver, C. M. Bioactive foods and ingredients for health. Adv. Nutr. 2014, 5, 306S-311S.

(4) Durand, T.; Bultel-Ponce, V.; Guy, A.; Berger, S.; Mueller, M. J.; Galano, J. M. New bioactive oxylipins formed by non-enzymatic freeradical-catalyzed pathways: the phytoprostanes. Lipids 2009, 44, 875888.

(5) Medina, S.; Domínguez-Perles, R.; Gil, J. I.; Ferreres, F.; GarcíaViguera, C.; Martínez-Sanz, J. M.; Gil-Izquierdo, A. A ultra-pressure liquid chromatography/triple quadrupole tandem mass spectrometry method for the analysis of 13 eicosanoids in human urine and quantitative $24 \mathrm{~h}$ values in healthy volunteers in a controlled constant diet. Rapid Commun. Mass Spectrom. 2012, 26, 1249-1257.

(6) Medina, S.; Dominguez-Perles, R.; Moreno, D. A.; GarciaViguera, C.; Ferreres, F.; Gil, J. I.; Gil-Izquierdo, A. The intake of broccoli sprouts modulates the inflammatory and vascular prostanoids but not the oxidative stress-related isoprostanes in healthy humans. Food Chem. 2015, 173, 1187-1194.

(7) Medina, S.; Gil-Izquierdo, A.; Durand, T.; Ferreres, F.; Dominguez-Perles, R. Structural/Functional Matches and Divergences of Phytoprostanes and Phytofurans with Bioactive Human Oxylipins. Antioxidants 2018, 7, No. 165.

(8) Parchmann, S.; Mueller, M. J. Evidence for the Formation of Dinor Isoprostanes E1from $\alpha$-Linolenic Acid in Plants. J. Biol. Chem. 1998, 273, 32650-32655.

(9) Forman, B. M.; Tontonoz, P.; Chen, J.; Brun, R. P.; Spiegelman, B. M.; Evans, R. M. 15-Deoxy-delta 12, 14-prostaglandin J2 is a ligand for the adipocyte determination factor PPAR gamma. Cell 1995, 83, $803-812$.

(10) Gilles, S.; Mariani, V.; Bryce, M.; Mueller, M. J.; Ring, J.; Jakob, T.; Pastore, S.; Behrendt, H.; Traidl-Hoffmann, C. Pollen-Derived E1Phytoprostanes Signal via PPAR- $\gamma$ and NF- $\kappa$ B-Dependent Mechanisms. J. Immunol. 2009, 182, 6653-6658.

(11) Kliewer, S. A.; Lenhard, J. M.; Willson, T. M.; Patel, I.; Morris, D. C.; Lehmann, J. M. A prostaglandin J2 metabolite binds peroxisome proliferator-activated receptor gamma and promotes adipocyte differentiation. Cell 1995, 83, 813-819.

(12) Narumiya, S. Y.; Ushikubi, F. Prostanoid receptors: structures, properties, and functions. Physiol. Rev. 1999, 79, 1193-1226.

(13) Collado-González, J. D.; Durand, T.; Ferreres, F.; Medina, S.; Torrecillas, A.; Gil-Izquierdo, A. Phytoprostanes. Lipids Technol. 2015, 27, 127-130.

(14) Leung, K. S.; Chen, X.; Zhong, W.; Yu, A. C.; Lee, C. Y. Microbubble-mediated sonoporation amplified lipid peroxidation of Jurkat cells. Chem. Phys. Lipids 2014, 180, 53-60.

(15) Yonny, M. E.; Rodríguez Torresi, A.; Cuyamendous, C.; Réversat, G.; Oger, C.; Galano, J.-M.; Durand, T.; Vigor, C.; Nazareno, M. A. Thermal Stress in Melon Plants: Phytoprostanes and Phytofurans as Oxidative Stress Biomarkers and the Effect of Antioxidant Supplementation. J. Agric. Food Chem. 2016, 64, 82968304.

(16) Lovrija, M. C.; Litvic, I.; Bartolincic, M.; Vinkovic, A.; Scope, V. and Limitations of Sodium and Potassium Trimethylsilanolate as Reagents for Conversion of Esters to Carboxylic Acids. Croatia Chemica Acta 2007, 80, 109-115.

(17) Liakh, I.; Pakiet, A.; Sledzinski, T.; Mika, A. Modern Methods of Sample Preparation for the Analysis of Oxylipins in Biological Samples. Molecules 2019, 24, No. 1639.

(18) Domínguez-Perles, R.; Teixeira, A. I.; Rosa, E.; Barros, A. I. Assessment of (poly)phenols in grape (Vitis vinifera L.) stems by using food/pharma industry compatible solvents and Response Surface Methodology. Food Chem. 2014, 164, 339-46. 
(19) Grosso, C.; Ferreres, F.; Gil-Izquierdo, A.; Valentao, P.; Sampaio, M.; Lima, J.; Andrade, P. B. Box-Behnken factorial design to obtain a phenolic-rich extract from the aerial parts of Chelidonium majus L. Talanta 2014, 130, 128-136.

(20) Prgomet, I.; Domínguez-Perles, R.; Pascual-Seva, N.; Barros, A. I.; et al. A Box-Behnken Design for Optimal Extraction of Phenolics from Almond By-products. Food Anal. Methods 2019, 12, 2009-2024.

(21) Cuyamendous, C.; Leung, K. S.; Durand, T.; Lee, J. C.; Oger, C.; Galano, J. M. Synthesis and discovery of phytofurans: metabolites of alpha-linolenic acid peroxidation. Chem. Commun. 2015, 51, $15696-15699$.

(22) Cuyamendous, C.; Leung, K. S.; Bultel-Poncé, V.; Guy, A.; Durand, T.; Galano, J. M.; Lee, J. C. Y.; Oger, C. Total synthesis and in vivo quantitation of phytofurans derived from $\alpha$-linolenic acid. Eur. J. Org. Chem. 2017, 2017, 2486-2490.

(23) El Fangour, S.; Guy, A.; Despres, V.; Vidal, J. P.; Rossi, J. C.; Durand, T. Total synthesis of the eight diastereomers of the syn-antisyn phytoprostanes F1 types I and II. J. Org. Chem. 2004, 69, 24982503.

(24) Guy, A.; Flanagan, S.; Durand, T.; Oger, C.; Galano, J. M. Facile synthesis of cyclopentenone B1- and L1-type phytoprostanes. Front. Chem. 2015, 3, 41.

(25) Collado-González, J.; Medina, S.; Durand, T.; Guy, A.; Galano, J.-M.; Torrecillas, A.; Ferreres, F.; Gil-Izquierdo, A. New UHPLC$\mathrm{QqQ}-\mathrm{MS} / \mathrm{MS}$ method for quantitative and qualitative determination of free phytoprostanes in foodstuffs of commercial olive and sunflower oils. Food Chem. 2015, 178, 212-220.

(26) Pinciroli, M.; Domínguez-Perles, R.; Abella'n, A.; Guy, A.; Durand, T.; Oger, C.; M Galano, J.; Ferreres, F.; Gil-Izquierdo, A. Comparative Study of the Phytoprostane and Phytofuran Content of indica and japonica Rice (Oryza sativa L.) Flours. J. Agric. Food Chem. 2017, 65, 8938-8947.

(27) Kulkarni, N.; Gadre, R. V. Production and properties of an alkaline, thermophilic lipase from Pseudomonas fluorescens NS2W. J. Ind. Microbiol. Biotechnol. 2002, 28, 344-348.

(28) Matsunaga, A.; Koyama, N.; Noso, Y. Purification and properties of esterase from Bacillus stearothermophilus. Arch. Biochem. Biophys. 1974, 160, 504-513.

(29) Domínguez-Perles, R.; Abellan, A.; Leon, D.; Ferreres, F.; Guy, A.; Oger, C.; Galano, J. M.; Durand, T.; Gil-Izquierdo, A. Sorting out the phytoprostane and phytofuran profile in vegetable oils. Food Res. Int. 2018, 107, 619-628.

(30) Jahn, E. D. T.; Galano, J. M.; Jahn, U. Recent approaches to the total synthesis of phytoprostanes, isoprostanes and neuroprostanes as important products of lipid oxidative stress and biomarkers of disease. Chemické Listy 2014, 108, 301-319.

(31) Cuyamendous, C.; de la Torre, A.; Lee, Y. Y.; Leung, K. S.; Guy, A.; Bultel-Ponce, V.; Galano, J. M.; Lee, J. C.; Oger, C.; Durand, T. The novelty of phytofurans, isofurans, dihomo-isofurans and neurofurans: Discovery, synthesis and potential application. Biochimie 2016, 130, 49-62.

(32) Barden, A. E.; Croft, K. D.; Durand, T.; Guy, A.; Mueller, M. J.; Mori, T. A. Flaxseed oil supplementation increases plasma F1phytoprostanes in healthy men. J. Nutr. 2009, 139, 1890-1895.

(33) García-García, M. C.; del Río Celestino, M.; Gil-Izquierdo, Á.; Egea-Gilabert, C.; Galano, J. M.; Durand, T.; Oger, C.; Fernández, J. A.; Ferreres, F.; Domínguez-Perles, R. The Value of Legume Foods as a Dietary Source of Phytoprostanes and Phytofurans Is Dependent on Species, Variety, and Growing Conditions. Eur. J. Lipid Sci. Technol. 2019, 121, No. 1800484.

(34) Medina, S.; Dominguez-Perles, R.; Cejuela-Anta, R.; Villano, D.; Martinez-Sanz, J. M.; Gil, P.; Garcia-Viguera, C.; Ferreres, F.; Gil, J. I.; Gil-Izquierdo, A. Assessment of oxidative stress markers and prostaglandins after chronic training of triathletes. Prostaglandins Other Lipid Mediators 2012, 99, 79-86.

(35) Medina, S.; Miguel-Elizaga, I. D.; Oger, C.; Galano, J. M.; Durand, T.; Martinez-Villanueva, M.; Castillo, M. L.; VillegasMartinez, I.; Ferreres, F.; Martinez-Hernandez, P.; Gil-Izquierdo, A. Dihomo-isoprostanes-nonenzymatic metabolites of AdA-are higher in epileptic patients compared to healthy individuals by a new ultrahigh pressure liquid chromatography-triple quadrupole-tandem mass spectrometry method. Free Radical Biol. Med. 2015, 79, 154-163.

(36) Godinho, L. F.; Reis, C. R.; Tepper, P. G.; Poelarends, G. J.; Quax, W. J. Discovery of an Escherichia coli esterase with high activity and enantioselectivity toward 1,2-O-isopropylideneglycerol esters. Appl. Environ. Microbiol. 2011, 77, 6094-6099.

(37) Sayali, K.; Sadichha, P.; Surekha, S. Microbial Esterases: An overview. Int. J. Curr. Microbiol. Appl. Sci. 2013, 2, 135-146.

(38) Bain, B. J.; Bates, I.; Bradshaw, A. E.; Briggs, C.; Burthem, J.; Cantwell, C.; Carter, J. Y.; De la Salle, B.; Foroni, L.; Gerrard, G.; Harrington, D. J.; Hing, S.; Laffan, M. A.; Layton, M.; Mitchell Lewis, S.; Manning, R. A.; May, A. M.; McNamara, C.; Milkins, C.; Morilla, R.; Morilla, A. M.; Nadal-Melsió, E.; Nijran, K. S.; Osei-Bimpong, A.; Perry, D. J.; Regan, F. A. M.; Reid, A. G.; Richards, S. J.; Robertson, L. D.; Roper, D.; Rowley, M.; Thachil, J.; Toma, S.; Wild, B. J.; Win, N.; Worwood, M. Contributors. In Dacie and Lewis Practical Haematology, 12th ed.; Bain, B. J.; Bates, I.; Laffan, M. A., Eds.; Elsevier, 2017; pp $7-9$.

(39) Ferreira, S. L.; Bruns, R. E.; Ferreira, H. S.; Matos, G. D.; David, J. M.; Brandao, G. C.; da Silva, E. G.; Portugal, L. A.; dos Reis, P. S.; Souza, A. S.; dos Santos, W. N. Box-Behnken design: an alternative for the optimization of analytical methods. Anal. Chim. Acta 2007, 597, 179-186.

(40) Beaufay, H.; Amar-Costesec, A.; Thinès-Sempoux, D.; Wibo, M.; Robbi, M.; Berthet, J. Analytical study of microsomes and isolated subcellular membranes from rat liver. 3. Subfractionation of the microsomal fraction by isopycnic and differential centrifugation in density gradients. J. Cell Biol. 1974, 61, 213-231.

(41) Mariani, V.; Gilles, S.; Jakob, T.; Thiel, M.; Mueller, M. J.; Ring, J.; Behrendt, H.; Traidl-Hoffmann, C. Immunomodulatory mediators from pollen enhance the migratory capacity of dendritic cells and license them for Th2 attraction. J. Immunol. 2007, 178, 7623-7631.

(42) Wierdl, M.; Tsurkan, L.; Hyatt, J. L.; Edwards, C. C.; Hatfield, M. J.; Morton, C. L.; Houghton, P. J.; Danks, M. K.; Redinbo, M. R.; Potter, P. M. An improved human carboxylesterase for enzyme/ prodrug therapy with CPT-11. Cancer Gene Ther. 2008, 15, 183-192.

(43) Box, G. E. P.; Behnken, D. W. Some New Three Level Designs for the Study of Quantitative Variables. Technometrics 1960, 2, 455475 .

(44) Bayar, N.; Friji, M.; Kammoun, R. Optimization of enzymatic extraction of pectin from Opuntia ficus indica cladodes after mucilage removal. Food Chem. 2018, 241, 127-134.

(45) Taylor, J. I.; Grace, P. B.; Bingham, S. A. Optimization of conditions for the enzymatic hydrolysis of phytoestrogen conjugates in urine and plasma. Anal. Biochem. 2005, 341, 220-229.

(46) Salwanee, S.; Mustapha, W. A.; Mamot, S.; Maskat, M. Y.; et al. Effects of enzyme concentration, temperature, ph and time on the degree of hydrolysis of protein extract from viscera of tuna (Euthynnus affinis) by using alcalase. Sains Malasia. 2013, 42, 279-287.

(47) Guerard, F.; Guimas, L.; Binet, A. Production of tuna waste hydrolysates by a commercial neutral protease preparation. J. Mol. Catal. B: Enzym. 2002, 19-20, 489-498.

(48) Mukhin, V. A.; Novikov, V. Y. Enzymatic Hydrolysis of Proteins from Crustaceans of the Barents Sea. Appl. Biochem. Microbiol. 2001, 37, 538-542. 